【論文】

\title{
建設資材の管理・配送計画のシステム化に関する研究 \\ STUDY ON A SYSTEMS APPROACH TO MANAGEMENT AND DELIVERY PLANNING PROCESS OF CONSTRUCTION EQUIPMENTS
}

\author{
吉 川和 広* ・ 山本幸 司**・見波潔*** \\ By Kazuhiro YOSHIKAWA, Koshi YAMAMOTO and Kiyoshi MINAMI
}

\section{1. 緒言}

建設工事は属地生産といら特性をもつため, 各工事現 場が必要とする時期に必要な種類・数量・品質の建設機 械や仮設資材を確実に搬入することが工事遂行上の必須 条件となる.したがって, 多種類の建設機械や仮設資材 を多量に使用する現状では, これらの購入・管理・運用 方法に関する検討が不十分であれば，工事施工における 所期の管理目標を十分に達成し得なくなり，場合によっ ては上述した必須条件すら満足できなくなる.

そこで多くの施工組織体では主として以下のような業 務を行ら資材センター（別称, 機材センター, 工作所な ど）を設置し，この問題に対処している.

(1) 各工事現場が必要とする機械・資材の数量を予測 し，不足分を新規購入すべきかどうか判断する.

(2) 各工事現場から機械・資材の搬入要請があれば, その種類・数量・品質を確認し, 必要に応じてリース制 度を利用し，指定された日時に当該現場へ配送する。

(3) 機械・資材の使用負担として各工事現場から供用 日数に応じた使用料を徵収する.

(4) 工事現場から返送された機械・資材を点検・修理 し, 保管する. また, 以後の使用に耐えないと判断され る機械・資材は廃棄処分とする.

このよらな資材センターの業務は工事遂行上重要な位 置を占めるにもかかわらず, 各担当者が経験に基づいて 主観的・恣意的に意志決定することが多く, 資材セン ター本来の機能を十分に遂行し得ていないのが現状であ る.

そこで本研究では, 上述した資材センターの諸業務の 中でも建設工事の管理目標に及ぼす影響が特に大きいと

* 正会員 工博 京都大学教授 工学部土木工学科

** 正会員 工博 名古屋工業大学講師 土木工学科

*** 正会員 工修 建設省士木研究所施工研究室研究員
考えられる購入・管理・運用業務と配送業務を取り上 げ，合理的な購入・管理・運用計画 (以下, 単に管理計 画とよぶ）および配送計画の策定方法を提案する.ここ でいう合理的な管理・配送計画とは, 各工事現場で必要 とする種類・数量 - 品質の機械・資材を必要な時期に確 実に配送することを制約条件と考え, 購入・管理・運用 に要する費用拉よび配送費用を低廉化することを目的と するものであり, 計画モデルの策定にあたっては, 代替 案を体系的に比較評価し得るシステムズ・アナリシス的 なアプローチを試みることにする ${ }^{11}$.

なお, 資材センターで取り扱ら機械・資材は一般に単 品管理品目と数量管理品目とに大別できるが,

(1) 単品管理品目は購入価格が高いために重点的な管 理・運用が必要であるが, 取扱い数量が少ないため従来 の方法でも十分に対処できること，

(2) 数量管理品目, 特に仮設資材は購入価格が比較的 低廉であるが，取扱い数量が多く使用頻度も高いため運 用方法・配送方法に関する代替案の数が多くなり, 従来 の方法では合目的度の高い計画立案が困難なこと， などを考慮し, 本研究では仮設資材を研究対象として取 り上げ，その管理・配送計画のシステム化を試みる.

以下，2. では資材管理・配送計画の概要を述べ， 3., 4. では合理的な計画策定を目的とした資材管理計画モ デルおよび配送計画モデルを提案するとともに，いくつ かの適用事例に対して実証的な考察を行らことにする.

\section{2. 資材管理・配送計画の概要 ${ }^{2) \sim 4}$}

\section{（1）資材管理・配送計画の計画対象}

仮設資材を運用上の特徴から分類すると，

(1) 耐用年数が比較的長く, 材質的にも多数回の転用 が可能であるため, 各工事現場へ賃貸する仮設資材

(2) 数回以下の使用でスクラップ同様になり転用が困 
難となるため, 各工事現場 に売却する仮設資材

の 2 種類に大別できるが, 本研究では前者に属する仮 設資材を取り上げ，以下こ れを単に資材とよぶことに

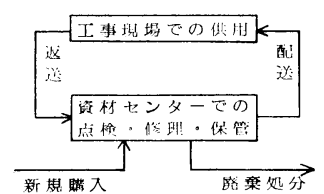

図一1資材運用のモデル図
する. いま資材の一般的な運用手順をモデル的に表わし たのが図一1である.このように資材はサイクリックに 使用されるため，その管理計画においては， (a 各種資 材をどれだけ保有し，(b) それをいかに効率的に運用す るか，を合理的に決定する必要がある.

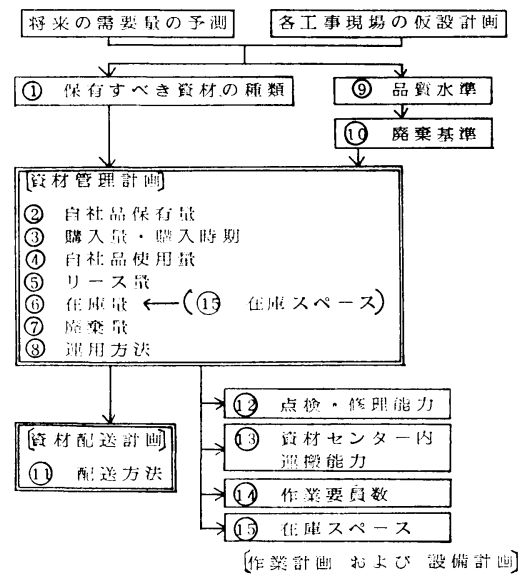

図一2 資材管理のプロセス

次に資材センターの業務内容を分析した結果, 図一2 に示すような資材管理プロセスが提案できた。このうち 本研究では, 個々の工事施工と密接に関係するためにシ スティマティックな取扱いを必要とする (2)〜 (8) の各要 素を合理的に決定する問題を特に資材管理計画とよぶこ とにする。 また，(11) 配送方法を決定する問題を資材配 送計画とよび，資材管理計画の下位計画として位置付け ることとする.

\section{（2）資材管理計画の概要}

施工組織体では工事受注後直ちに施工計画の作成業務 に入り，その成果の一つである仮設資材計画によって明 らかとなる必要資材の種類 ・ 数量・品質および供用時期 に関する内容は直ちに資材センターに報告される. 通常 この段階で得る情報の精度は 1 週間〜 1 か月を単位とす るおおまかなものであるが，資材センターではこれをも とにして資材の種類 ごとに 自社品の使用状況, 在庫状 況，返送予定などを調查したらえで，各工事現場に対し て自社品（新規購入品を含む），リース品のいずれを供 給すべきかを判断しなければならない。ささらに各工事現 場から搬入希望日の 1 2 週間前に送付される物品請求
書に基づいて当該工事現場に供給する自社品, リース品 の配送時期，数量を正式に決定する必要がある。

各工事現場の資材需要に対して自社品, リース品のい ずれを供給するかの判断は資材管理の中核をなすもので あり,これは（1）で述べたように，(a) 保有数量, (b 運 用方法を決定する問題と考えることができる，いうまで もなく両者は互いに密接な関係にあるが，本研究では，

（a) 保有数量の決定は, 資材の耐用年数が 5 年程度も しくはそれ以上であることを考慮して長期的展望に立つ べき計画問題であること，

(b) 運用方法の決定は, 各工事の資材使用計画が明ら かになった段階で初めて検討が可能となる比較的短期間 を対象とする計画問題であること，

を考慮して資材管理計画を長期計画と短期計画とに分 け，前者では資材の長期需要予測をもとに望ましい保有 数量を求める問題を扱い, 後者では各工事の資材使用計 画をもとに運用方法 (新規購入量, 自社品使用量, リー ス量の決定）を求める問題を扱うことにした.

ここで従来の資材管理方式を振り返ってみると，担当 者がそれぞれの経験・勘を頼りに意志決定を行うため,

（i） 運用方法に関する意志決定が場当たり的で，時 として資材調達業務の確実性を損なら恐れがあること，

（ii） 運用方法の代替案数が多いため, 望をしい代替 案を限られた時間内に選択することが困難なこと，

'（iii）資材管理の良否は調達業務の確実性のみならず 資材管理費用の損益計算によっても評価されるにもかか

\section{表一1 資材管理費用の内訳}

（a）収支形態 1 の場合

\begin{tabular}{|c|c|c|}
\hline 主 体 収支別 & 支 & 収 \\
\hline$A_{1}$ : 現 場 & $\begin{array}{l}\text { 自社品使用料, リース料 } \\
\text { 輸送費, 廃裹处分補償費 } \\
\text { (自社品, リース品) }\end{array}$ & \\
\hline $\mathrm{B}_{1}$ : 餈ンター & $\begin{array}{l}\text { 在庫管理費, 新規購入費 } \\
\text { 修理費 }\end{array}$ & $\begin{array}{l}\text { 自社品使用料 } \\
\text { 廃棄処分補僋費 } \\
\text { (自社品) }\end{array}$ \\
\hline$C$ : 支 店 & $\begin{array}{l}\text { 在庫管理費, 新規購入費 } \\
\text { 修理費, リース } \\
\text { 発棄処分補償費（リース品） }\end{array}$ & \\
\hline
\end{tabular}

（b）収支形態 2 の場合

\begin{tabular}{|c|c|c|}
\hline 主 体 収支別 & 支出 & 収 \\
\hline $\mathrm{A}_{2}$ ：現 場 & $\begin{array}{l}\text { 自社品使用料, 輸送費 } \\
\text { 廃率処分補償費 } \\
\quad \text { (自社品, リース品) }\end{array}$ & \\
\hline $\mathrm{B}_{2}$ : 瓷 センター & $\begin{array}{l}\text { 在庫管理費, 新規購入費 } \\
\text { 修理費, リース料と自社品 } \\
\text { 使用料の差額 }\end{array}$ & 上表と同じ \\
\hline $\mathrm{C}$ : 支 & 上表と同じ & \\
\hline
\end{tabular}


わらず，これに対する考察が不十分であること，

などの問題点を指摘することができる．そこで次章では 工事施工に必要な資材の確実な供給を制約条件とし，資 材管理費用の低廉化といら客観的な評価基準のもとで望 ましい代替案を選択し得る計画モデルを提案する。

なお本研究では評価主体として, 主体 $\mathrm{A}$; 個々の現場 レベル, 主体 B ; 資材センターレベル, 主体 C; 資材セ ンターと現場を包含する支店レベル，を考え，さらにリ 一ス料の負担形態として, 収支形態 1 ; 全額を現場が負 担する形態，収支形態 2 ; リース料と自社品使用料の差 額を資材センターが負担する形態，を考えていくことと し，資材管理に関連する費用として 表一1に示す各項目 を取り上げた.なお表では保有数量に関係しない固定経 費を除外している．さて上述した 3 つ評価主体のうち 主体 $\mathrm{A}$ 場合には各工事現場が独立に資材計画を検討す ることになるため本研究の対象とはなり得ない．そこで 以下では主体 B およびCの立場から経済性の評価を行う ことにする.

\section{（3）資材配送計画の概要}

各工事現場からの資材搬入要請は資材管理計画に基つ いて自社品もしくはリース品で賄われるが，資材センタ 一が配送業務の対象とするのは自社品である．しかも現 実には配送業務を運送業者に委託することが多く，従来 は配送すべき資材の数量・配送日時・配送先を指示する 程度で, 個々のトラックへの積載数量や配送ルートを具 体的に検討することはほとんどなかった．しかしこれで は積載効率の低いトラックを数多く配車する可能性が大 であり，配送費用の増大を招く一因となっていた。

そこで本研究では，各現場への自社品の確実な配送を 制約条件とし，配送ルートの統合扝よび複数種類の資材 の混載を積極的に導入することによって配送費用の低廉 化を図る資材配送計画の策定方法を提案する.このよう な資材配送計画は各工事現場の自社品使用量を対象に配 送業務の合理化を検討するものであるため, 資材管理計 画のアウトプット情報を資材配送計画へのインプット情 報として利用することができることから，2 つの計画は 有機的に結合することになる.

\section{3. 資材管理計画モデル}

資材センターでは多種類の資材を取り扱らが，ここで は単一種類の資材を対象とする資材管理計画モデルを提 案することとし，モデル化に際しては，

(1) 長期計画の計画対象期間は対象資材の耐用年数程 度とし，これをいくつかの期に分割する.

(0) 短期計画の計画対象期間は長期計画の第 1 期と対
応し，これをさらにいく つかの期に分割する。

(2したがって以下に おいては長期計画はその 第 2 期以降を対象とす る。

を前提として図一3に示

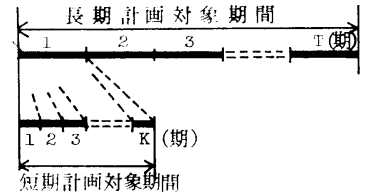

図一3資材管理計画モデル の対象期間の分割 すように計画対象期間および期を設定する。

\section{（1）長期計画モデルの定式化}

この計画モデルは資材センターの管轄内で発生する資 材の需要に対して自社品およびリース品を供給するとい う条件下で，資材管理費用の低廉化を評価基準として望 ましい自社品保有数量を決定するものであるが，モデル 化にあたっては以下のような前提条件を考えた.

(1) 自社品使用量, 在庫量, リース量と自社品保有 量, 需要量との間には次に示す関係があるものとする。

$$
\left.\begin{array}{l}
\text { 自社品使用量 }=\min \{\rho H, D\} \\
\text { 在庫量 }=\max \{H-\rho H, H-D\} \\
\text { リース量 }=\max \{D-\rho H, 0\}
\end{array}\right\}
$$

ただし， $H$ : 自社品保有量, $D$ : 需要量, $\rho$ : 自社品稼 働率の上限值

これは, リース品は自社品が不足する場合に補助的に利 用されること，および自社品については現場での供用後 資材センターでの点検・修理期間が必要であるため稼働 率には上限が存在することを考慮したものである.

(2) 各期の需要量は確率分布形で与えるものとする.

(3) 各期末には当該期の使用量に比例する減耗が生じ るものとするが, 資材の売却は行わないものとする.

(4) 各期の修理費は当該期の使用量に比例するものと する.

\begin{tabular}{|c|c|c|c|c|}
\hline 記 & & 号 & 内 & 容 \\
\hline$H_{t}$ & \multicolumn{2}{|c|}{ (決定変数) } & 第 $t$ 期の自社品 & \\
\hline$I_{t}$ & \multicolumn{2}{|c|}{ （補助変数） } & 第 $t$ 期の在庫量 & \\
\hline$S_{t}$ & \multicolumn{2}{|c|}{ （補助変数） } & 第 $t$ 期の自社品 & \\
\hline$R_{t}$ & \multicolumn{2}{|c|}{ （補助変数） } & 第 $t$ 期のリース & \\
\hline$X_{t}$ & \multicolumn{2}{|c|}{ （補助変数） } & 第 $t$ 期の新規䁚 & \\
\hline$\rho$ & （定 & 数) & 自社品稼働率 & \\
\hline$p$ & （定 & 数) & 廃毫処分減耗率 & \\
\hline$C_{t}^{I}$ & （定 & 数) & 第 $t$ 期の在庫 1 & 档理費 \\
\hline$C_{t k} s$ & （定 & 数） & $\begin{array}{l}\text { 第 } k \text { 期の新規 } \\
\text { 当当り損料 }\end{array}$ & $t$ 期での 1 単 \\
\hline$C_{t}^{U}$ & （定 & 数) & 第 $t$ 期の自社品 & 使用料 \\
\hline$C_{t}^{M}$ & （定 & 数) & 第 $t$ 期の自社品 & 修理費 \\
\hline$C_{t}{ }^{R}$ & （定 & 数) & 第 $t$ 期の 1 単位 & \\
\hline$C_{t}^{B}$ & （定 & 数) & 第 $t$ 期の自社品 & 筆処分補償費 \\
\hline$C_{t}^{B^{\prime}}$ & （定 & 数) & 第 $t$ 期のリー & 童処分補償費 \\
\hline \multicolumn{3}{|c|}{$\varphi_{t}(D) d D($ 定数 $)$} & 第 $t$ 期の需要最 & の間である確率 \\
\hline \multirow{2}{*}{\multicolumn{3}{|c|}{$\begin{array}{c}z_{B_{1}}{ }^{(1)}, z_{B 2}{ }^{(1)}, z_{C^{(1)}} \\
H_{1}{ }^{E}\end{array}$}} & 短期計画モデル & \\
\hline & & & 第 1 期末の自社 & \\
\hline
\end{tabular}

（5) 新規購入は各期首に行われ，購入費用は償却費と

表一2 長期計画モデルの記号説明 
して以後の各期に振り分けるものとする.

(6) 資材管理費用の期待值の 最小化を評価基準とす z.

以下ではこのような前提条件のもとでの長期計画モデ ルを示す. なお，各記号の説明は表一2 に示す.

<主体 $\mathrm{B}$, 収支形態 1 の場合 $\left(\mathrm{B}_{1}\right.$ と芳す) > (目的関数)

$$
\begin{aligned}
Z_{B_{1}}= & \left(z_{B_{1}(1)}+\sum_{t=2}^{T} C_{t 1}{ }^{s} X_{1}\right) \\
& +\sum_{t=2}^{T}\left[C_{t}{ }^{I} I_{t}+\sum_{k=2}^{t} C_{t k}{ }^{s} X_{k}+C_{t}{ }^{M} S_{t}-C_{t}{ }^{U} S_{t}\right. \\
& \left.-C_{t}{ }^{B}\left(p \cdot S_{t}\right)\right] \rightarrow \min \ldots \ldots \ldots \ldots \ldots \ldots(2)
\end{aligned}
$$

(制約条件)

$$
\begin{aligned}
& H_{t} \geqq H_{t-1}-p S_{t-1} \quad(t=3,4, \cdots, T) \\
& H_{2} \geqq H_{1}{ }^{E} \cdots \cdots \cdots \cdots \cdots \cdots \cdots \cdots \cdots \cdots \cdots \cdots \cdots \cdots \cdots \cdots \cdots \cdots \cdots \\
& H_{t} \geqq 0 \quad(t=2,3, \cdots, T)
\end{aligned}
$$
ただし，

$$
\begin{aligned}
I_{t}= & \left.\int_{0}^{\rho H_{t}}\left(H_{t}-D\right) \varphi_{t}(D) d I\right) \\
& +\int_{\rho H_{t}}^{\infty}(1-\rho) H_{t} \varphi_{t}(D) d D \quad(t=2,3, \cdots, T)
\end{aligned}
$$

$$
\begin{array}{r}
\left.\left.\left.S_{t}=\int_{0}^{\rho H_{t}} D \varphi_{t}(I)\right) d I\right)+\int_{\rho H_{t}}^{\infty} \rho H_{t} \varphi_{t}(D) d I\right) \\
(t=2,3, \cdots, T) \cdots \cdots \cdots \cdots \cdots \\
H_{t}=I_{t}+S_{t} \quad(t=2,3, \cdots, T) \cdots \cdots \cdots \cdots \cdots \\
X_{t}=H_{t}-\left(H_{t-1}-p S_{t-1}\right) \quad(t=3,4, \cdots, T)
\end{array}
$$

$X_{2}=H_{2}-H_{1}{ }^{E}$

$$
\int_{0}^{\infty} \varphi_{t}(D) d D=1 \quad(t=2,3, \cdots, T)
$$

この定式化において, $z_{B_{1}{ }^{(1)}}, X_{1}, H_{1}{ }^{E}$ は後述する短 期計画モデルの目的関数および变数である. 式 (2) は計 画対象期間内の資材管理費用の期待值を表わしており, 右辺の各項は 表一1 に示した経費の内訳と対応してい る. 式 (3), (4) は, 各期の自社品保有量はその直前の 保有量から減耗分を差し引いた量よりも多いことを表わ しており，その際に前提条件 (3) を考虑している.この 制約条件は式 (9)，(10) で表わされる新規購入量 $X_{t}$ の 非負条件を与えていることに等しい。 また, 式 (6)，(7) は在庫量, 自社品使用量の期待值を表わしており, 前提 条件 (1) に従って需要量 $D$ が $\rho H$ よりも大きい場合と 小さい場合に分けて計算を行っている.

$<$ 主体 $\mathrm{B}$, 収支形態 2 の場合 $\left(\mathrm{B}_{2}\right.$ と記す $)>$ (制約条件)

$\mathrm{B}_{1}$ の場合と同じ.

(目的関数)

$$
\begin{aligned}
Z_{B_{2}}= & \left(z_{B_{2}(1)}+\sum_{t=2}^{T} C_{t 1}{ }^{s} X_{1}\right) \\
& +\sum_{t=2}^{T}\left[C_{t}^{I} I_{t}+\sum_{k=2}^{t} C_{t k}{ }^{S} X_{k}+C_{t}{ }^{M} S_{t}\right. \\
& +\left(C_{t}{ }^{R}-C_{t}{ }^{U}\right) R_{t}-C_{t}{ }^{U} S_{t} \\
& \left.-C_{t}{ }^{B}\left(p S_{t}\right)\right] \rightarrow \min \ldots \ldots \ldots \ldots \ldots \ldots
\end{aligned}
$$

ただし，

$$
\begin{aligned}
& \left.R_{t}=\int_{\rho H_{t}}^{\infty}\left(D-\rho H_{t}\right) \varphi_{t}(D) d I\right)(t=2,3, \cdots, T) \\
& S_{t}+R_{t}=\int_{0}^{\infty} D \varphi_{t}(D) d D=\mu_{t} \quad(t=2,3, \cdots, T)
\end{aligned}
$$

<主体 Cの場合 ( C と記す) $>$ (制約条件)

$\mathrm{B}_{1}$ の場合と同じ.

(目的関数)

$$
\begin{aligned}
Z_{C}= & \left(z_{C}{ }^{(1)}+\sum_{t=2}^{T} C_{t 1}{ }^{s} X_{1}\right) \\
& +\sum_{t=2}^{T}\left[C_{t}^{I} I_{t}+\sum_{k=2}^{t} C_{t k}{ }^{s} X_{k}+C_{t}{ }^{M} S_{t}\right. \\
& \left.+C_{t}{ }^{R} R_{t}+C_{t}{ }^{B^{\prime}}\left(p R_{t}\right)\right] \rightarrow \min \cdots \cdots
\end{aligned}
$$

これらのうちCでは評価基準に輸送費を含めるべきで あるが，長期計画は各現場への輸送費を個々に算出し得 るレベルではないことを考虑して輸送費を目的関数から 除外した.

\section{（2）長期計画モデルの解法}

上述したモデルは目的関数式や制約条件式 (4) からも わかるよ5に, 第 2 期以降に関する長期計画と第 1 期の みを対象とする短期計画といらレベルの異なる 2 つ問 題を含んでいるため, 両者の最適解を同時に得ることは 実際上, 非常に困難と思われる. そこで, 本研究では最 初に長期計画について優先的に最適化を図り, その得ら れた解の範囲内で短期計画の最適化を図ることを考え た. すなわち, 長期計画問題では制約条件式 (4) を考慮 からはずして第 2 期以降の最適解 $H_{t} *(t=2,3, \cdots, T)$ を求め, 式 (4) は後述する短期計画モデルの制約条件と して扱らことにした.

ここではまず $H_{t}{ }^{*}$ を求める方法について述べる.

本モデルの性質から目的関数は $H_{t}$ に関して極值をも つことが予想されるため，

$$
\partial Z / \partial H_{t}=0 \cdot \cdot
$$

となる $H_{t}$ を求める. 一例として式 (2)より式 (16) を 導くと

$$
\int_{0}^{\rho H_{t}} \varphi_{t}(D) d D
$$




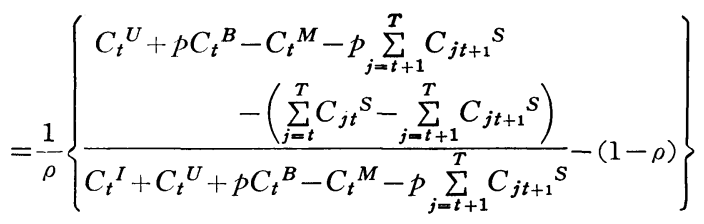

となり，これを満足する $H_{t}$ は解析的にあるいは収束計 算等の方法により求めることができる. しかし，上述し た解法では制約条件式（3）を直接考慮していないため, 式 (17) の解 $\tilde{H}_{t}$ が式 (3) を満足すれば $\tilde{H}_{t}$ は最適解 $H_{t}{ }^{*}$ となるものの, 満足しない場合も当然考えられる. たとえば $\tilde{H}_{t-1}$ と $\tilde{H}_{t}$ が式 (3) を満足しない場合を想 定すると, 第 $t-1$ 期に $\tilde{H}_{t-1}$ を越えて新規購入するこ とはあり得ないため,このような場合には $\tilde{H}_{t-1}$ の決定 を保留し，

$$
\tilde{H}_{t-2}-p \tilde{S}_{t-2} \leqq H_{t-1} \leqq \tilde{H}_{t-1}
$$

の範囲内でいくつかの $H_{t-1}$ を想定し，

$$
H_{t}=H_{t-1}-p S_{t-1}
$$

といら関係から得られる $H_{t}$ と $H_{t-1}$ に対して最も合目 的度の高い値を新たに $\tilde{H}_{t-1}, \tilde{H}_{t}$ と打く方法を考えるこ とにする.このような方法を第 2 期から順次段階的に繰 り返していけば満足解を効率よく探索することができ る.

\section{（3）長期計画モデルの適用例}

以下では角パイプを対象品目として長期計画モデルの 適用を試みる. 本節では角パイプの耐用年数を 5 年とし これを半年単位で 10 期に分割した. 適用事例のインプ ットデータを表一3に示すが，ここでは便宜上角パイプ $100 \mathrm{~m}$ を 1 単位と考えた. 次に本モデルでは需要量を確 率的に取り扱うことを考慮しているが，現段階ではその 確率密度関数 $\varphi_{t}(D)$ を決定するための情報に乏しいた め, ここでは予測誤差の分布形としてしばしば用いられ る正規分布を仮定し，次式を用いることにした.

\begin{tabular}{c|c} 
表一3 & $\begin{array}{c}\text { 適用事例のイン } \\
\text { プットテータ }\end{array}$ \\
\hline$\rho$ & 0.9 \\
\hline$p$ & 0.05 \\
\hline$C_{t}{ }^{I}$ & 0 (円/単位) \\
\hline$C_{t k}{ }^{S}$ & 5640 (円/単位) \\
\hline$C_{t}{ }^{U}$ & 9600 (円/単位) \\
\hline$C_{t}{ }^{M}$ & 1500 (円/単位) \\
\hline$C_{t}{ }^{R}$ & 12000 (円/単位) \\
\hline$C_{t}{ }^{B}$ & 50000 (円/単位) \\
\hline$C_{t}{ }^{\prime}$ & 60000 (円/単位) \\
\hline$T$ & 10 (期) \\
\hline
\end{tabular}

(1 単位は $100 \mathrm{~m}$ )
表一4 適用事例のイン プットデータ

\begin{tabular}{c|c|c}
\hline & $\mu_{t}$ & $\sigma_{t}$ \\
\hline$t=2$ & 2561.6 & 249.8 \\
\hline$t=3$ & 2730.8 & 258.0 \\
\hline$t=4$ & 2900.0 & 267.9 \\
\hline$t=5$ & 3069.2 & 279.3 \\
\hline$t=6$ & 3238.4 & 292.0 \\
\hline$t=7$ & 3407.6 & 305.9 \\
\hline$t=8$ & 3576.8 & 320.8 \\
\hline$t=9$ & 3746.0 & 336.6 \\
\hline$t=10$ & 3915.2 & 353.2 \\
\hline
\end{tabular}

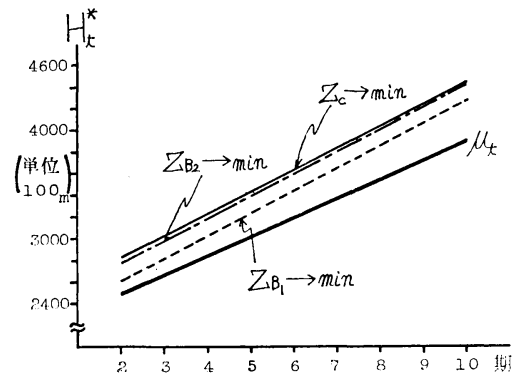

図一4 長期計画モデルの適用結果

$$
\begin{array}{r}
\varphi_{t}(D)=\frac{1}{\sqrt{2 \pi} \sigma_{t}} \exp \left\{-\frac{\left(D-\mu_{t}\right)^{2}}{2 \sigma_{t}{ }^{2}}\right\} \\
(t=2,3, \cdots, T) \cdots \cdots
\end{array}
$$

なお本研究では第 $t$ 期の平均 $\mu_{t}$ および標準偏差 $\sigma_{t}$ の 算定方法として，まず過去数年間の角パイプ使用実績を もとに時系列需要予測を行( ${ }^{5), 6)}$, 予測值 $A_{t}$ と信頼度 95\% の信頼限界の幅 $A_{t}$ を求め, これを用いて次式によ り $\mu_{t}, \sigma_{t}$ を定めることにした.

$$
\mu_{t}=A_{t}, \sigma_{t}=\frac{1}{2} \Delta_{t}(t=2,3, \cdots, T)
$$

ここで式 (21) の第 2 式は, 正規分布が

$$
P_{r}\left\{\mu_{t}-2 \sigma_{t} \leqq D \leqq \mu_{t}+2 \sigma_{t}\right\} \fallingdotseq 0.95
$$

といら性質をもつことを考虑して定めたものである. 適 用事例として用いた $\mu_{t}, \sigma_{t}$ の值は 表一4 に示寸.

以上のインプットデータを長期計画モデルに適用した 結果を示したのが 図一4 である.これより, $\mathrm{B}_{1}, \mathrm{~B}_{2}, \mathrm{C}$ のいずれの立場に立っても $H_{t}{ }^{*}$ は $\mu_{t}$ より大きいという 結果が得られたが，三者間には多少の差がみられる.す なわち， $B_{1}$ は施工組織体内部での 資材管理部門の独立 性が強い場合にその採算性を重規する立場であることか ら他の 2 ケースに比べて自社品保有量が少なくなってお り,この結果リース量が多少増加しても自社品の効率的 な運用を図ることになる。一方，C は資材管理部門と現 場を包含した支店レベルにおいて最も経済的な資材管理 を行おうとする立場であることから， $\mathrm{B}_{1}$ に比べて自社 品保有量は多くなっている. なお， $\mathrm{B}_{2}$ は $\mathrm{C}$ にきわめて 近い立場であることが 図一4 から判断できる.

\section{（4）短期計画モデルの定式化}

ここでは資材需要量が現場ごとに十分な精度で予測で きる期間を対象として, 新規購入量, リース量, 在庫量 を求め, 資材の運用方法を明らかにする計画モデルを提 案する. その際, 長期計画との整合性を保つために長期 計画モデルのアウトプットのらち第 2 期の自社品保有量 $\mathrm{H}_{2}{ }^{*}$ を制約条件の中で考慮することとし, 評価基準に関 しては長期計画と同様に $\mathrm{B}_{1}, \mathrm{~B}_{2}, \mathrm{C}$ を主体として資材管 理費用の最小化を考えることにする. 
本モデルの作成にあたっては長期計画モデルの前提条 件: (3)〜 (6) に加えて以下に示寸前提条件を考えた.

(1) 各工事の施工計画が作成された段階で資材センタ 一に報告される資材の必要時期は 1 週間〜 1 か月単位で 示されるのが一般的であるため, 計画単位もこの程度を 考えることにする。

(2) 各現場の資材需要量に対して自社品扩よびリース 品を必要時期に必要数量だけ供給するものとする.

(3) 自社品は各期首に資材センターから各現場へ配送 され，供用終了期の期末に資材センタ一へ返送されるも のとする.

(4) 資材センターへ返送された資材は 1 期間の点検 ・ 修理期間を経て, 次ヶ期には出庫可能な状態になるもの とする.

ところで資材の使用形態に関しては，同一現場内での 自社品とリース品の混合使用の可否，および同一現場内 での自社品とリース品の工期途中での切替使用の可否に より, 図一5 に示す 4 タイプに分類できる.このうち現 場で固定する使用方法の場合には中途切替が技術的に困 難であるため，ここではタイプ III，IV のみを取り上げ， その定式化を示す. なお各記号の意味内容は表一5 に示 したとおりである。

a) タイプII（混合使用可，中途切替不可）の定式化 現場の資材需要量が計画期によって変化する場合には 図一6に示すように当該現場をいくつかの仮想現場に分 割し, 各現場の需要量が計画期によらず一定となるよう にすれば定式化が容易になる.この結果, 主体 $\mathrm{B}_{1}$ に対 しては次のように定式化できる。

(目的関数)

$$
z_{B_{1}}{ }^{(1)}=\sum_{k=1}^{K}\left[\left\{\bar{C}_{k}{ }^{I} I_{k}+\sum_{i=1}^{k} \bar{C}_{k i}{ }^{S} P_{i}\right.\right.
$$

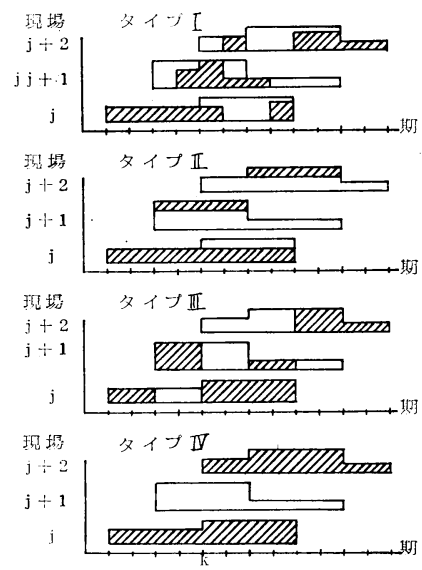

斜線は白社品使朋，己机以外はリー ス品伐用を少す。

図一5 資材使用形態の模式図
表一5 短期計画モデルの記号説明

\begin{tabular}{|c|c|c|c|}
\hline 記 & & to & 内 \\
\hline$P_{k}$ & \multicolumn{2}{|c|}{ （決定変数） } & 第 $k$ 期の新規購入量 \\
\hline$x_{j}$ & \multicolumn{2}{|c|}{ （決定変数） } & 現場 $\boldsymbol{j}$ での自社品使用量（タイプ II） \\
\hline$\delta_{j}$ & \multicolumn{2}{|c|}{ （決定変数） } & 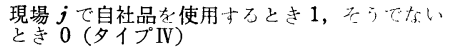 \\
\hline$I_{k}$ & \multirow{2}{*}{\multicolumn{2}{|c|}{$\begin{array}{l}\text { (補助変数) } \\
\text { (補助変数) }\end{array}$}} & 第 $k$ 期の在庫量 \\
\hline$H_{1}{ }^{E}$ & & & 最終期 (第 $K$ 期) の自社品保有量 \\
\hline$T_{k j}$ & （定 & 数) & 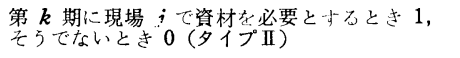 \\
\hline$E_{k j}$ & & 数) & 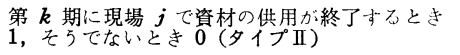 \\
\hline$m_{j}$ & （定 & 数) & 現場 $j$ の資材需要量 (タイプII) \\
\hline$m_{k j}$ & & 数) & 第 $k$ 期の現場 $j$ での資材需要量 (タイプIV) \\
\hline$I_{0}$ & & 数) & 初期在庫量 \\
\hline$B_{k}$ & & 数) & $\begin{array}{l}\text { 計画対象期間前に配送された資材の } 3 ち \text { 第 } k \text { 期 } \\
\text { 返送される量 }\end{array}$ \\
\hline$B_{0}$ & & 数) & $\begin{array}{l}\text { 計画対象期間前に配送された資材のうち計画対 } \\
\text { 象期間中には返送されない量 }\end{array}$ \\
\hline $\bar{S}_{k}, \underline{S}_{k}$ & & 数) & 第 $k$ 期の在庫量の上下限値 \\
\hline$M$ & & 数) & 新規購入費用の上限值 \\
\hline $\mathrm{H}_{2}{ }^{*}$ & & 数) & 長期計画モデルにおける第 2 期の適正保有量 \\
\hline & （定 & 数) & 供用 1 回当りの廃秉処分減耗率 \\
\hline \multicolumn{3}{|c|}{$C_{j}{ }^{T}, C_{j}{ }^{T^{\prime}}$ (定 数) } & $\begin{array}{l}\text { 資材センター执よびリース会社から現場 } j \text { への } \\
1 \text { 单位当り輸送費 }\end{array}$ \\
\hline \multicolumn{4}{|c|}{$\begin{array}{l}\text { なお, } \bar{C}_{k}{ }^{I}, \bar{C}_{k i} S, \bar{C}_{k}{ }^{M}, \bar{C}_{k} U, \bar{C}_{k}{ }^{R}, \bar{C}_{k} B, \bar{C}_{k} B^{\prime} \text { は長期計画モデルと } \\
\text { 同し意味内容 }\end{array}$} \\
\hline
\end{tabular}
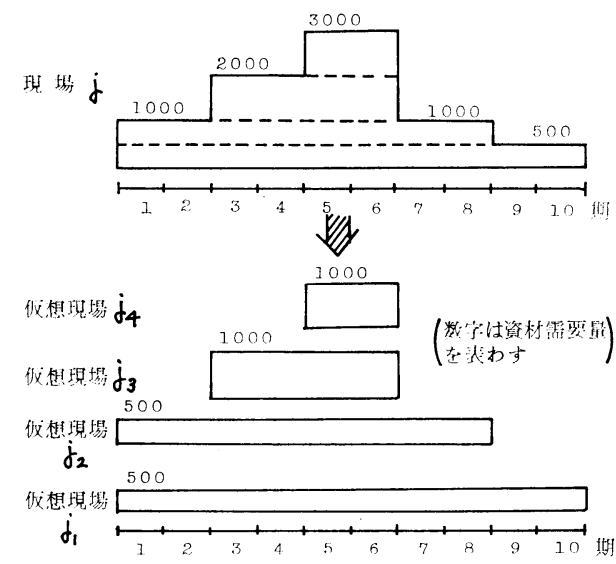

図一6 タイプ II における資材需要量の分割

$$
\begin{aligned}
& \left.+\bar{C}_{t}{ }^{M} \sum_{j=1}^{N} E_{k-1} x_{j}\right\}-\left\{\bar{C}_{t} U \sum_{j=1}^{N} T_{k j} x_{j}\right. \\
& \left.\left.+\bar{C}_{t}{ }^{B} \alpha \sum_{j=1}^{N} E_{k-1} j\right\}\right] \rightarrow \min \ldots \ldots \ldots \ldots . .
\end{aligned}
$$

ただし，

$$
\begin{aligned}
I_{k}=I_{0} & +(1-\alpha) \sum_{i=1}^{k-2} B_{i}+\sum_{i=1}^{k} P_{i}-\alpha \sum_{i=1}^{k} \sum_{j=1}^{N} E_{i} x_{j} \\
& +B_{k-1}+\sum_{j=1}^{N} E_{k-1} x_{j}-\sum_{j=1}^{N} T_{k} x_{j} \cdots \cdots
\end{aligned}
$$

（制約条件）

(1) 各期の自社品使用量は自社品供給可能量以下であ ること

$$
\sum_{j=1}^{N} T_{k} x_{j} \leqq I_{0}+(1-\alpha) \sum_{i=1}^{k-2} B_{i}+\sum_{i=1}^{k} P_{i}
$$




$$
\begin{array}{r}
-\alpha \sum_{i=1}^{k-2} \sum_{j=1}^{N} E_{i j} x_{j}-\sum_{j=1}^{N} E_{k-1} x_{j} \\
(k=1,2, \cdots, K) .
\end{array}
$$

(2) 各期の在庫量が一定範囲内にあること

$$
\underline{S}_{k} \leqq I_{k} \leqq \bar{S}_{k}(k=1,2, \cdots, K)
$$

(3) 新規購入費用の総額が上限值以下であること

$$
\sum_{k=1}^{K} C_{k}{ }^{P} P_{k} \leqq M
$$

(4) 最終期（第 $K$ 期）の自社品保有量は長期計画モ デルの第 2 期の保有量以下であること

$$
H_{1}{ }^{E} \leqq H_{2}{ }^{*}
$$

ただし，

$$
\begin{aligned}
& H_{1}{ }^{E}=I_{0}+B_{0}+(1-\alpha) \sum_{k=1}^{K} B_{k}+\sum_{k=1}^{K} P_{k} \\
& -\alpha \sum_{k=1}^{K-1} \sum_{j=1}^{N} E_{k} x_{j}
\end{aligned}
$$

(5) 新規購入量, 各現場の自社品使用量が一定範囲内 にあること

$$
\left.\begin{array}{ll}
P_{k} \geqq 0 & (k=1,2, \cdots, K) \\
0 \leqq x_{j} \leqq m_{j} & (j=1,2, \cdots, N)
\end{array}\right\}
$$

次に同じ制約条件のもとで主体 $\mathrm{B}_{2}, \mathrm{C}$ に対する目的 関数式を示す.

$$
\begin{aligned}
& z_{B_{2}}{ }^{(1)}=\sum_{k=1}^{K}\left[\left\{\bar{C}_{k}{ }^{I} I_{k}+\sum_{i=1}^{k} \bar{C}_{k i} S P_{i}+\bar{C}_{k}{ }^{M} \sum_{j=1}^{N} E_{k-1} x_{j}\right.\right. \\
& \left.+\left(\bar{C}_{k} R-\bar{C}_{k}^{U}\right) \sum_{j=1}^{N} T_{k j}\left(m_{j}-x_{j}\right)\right\} \\
& \left.-\left\{\bar{C}_{k} U \sum_{j=1}^{N} T_{k j} x_{j}+\bar{C}_{k}{ }^{B} \alpha \sum_{j=1}^{N} E_{k-1} x_{j}\right\}\right] \\
& \rightarrow \min \\
& z_{C}^{(1)}=\sum_{k=1}^{K}\left[\left\{\bar{C}_{k}^{I} I_{k}+\sum_{i=1}^{k} \bar{C}_{k i} S P_{i}+\bar{C}_{k}{ }^{M} \sum_{j=1}^{N} E_{k-1} x_{j}\right.\right. \\
& \left.+\bar{C}_{k} R \sum_{j=1}^{N} T_{k j}\left(m_{j}-x_{j}\right)\right\} \\
& \left.+\bar{C}_{k} B^{\prime} \alpha \sum_{j=1}^{N} E_{k-1}\left(m_{j}-x_{j}\right)\right] \\
& +\sum_{j=1}^{N} C_{j}{ }^{T} x_{j}+\sum_{j=1}^{N} C_{j}{ }^{T^{\prime}}\left(m_{j}-x_{j}\right) \rightarrow \min
\end{aligned}
$$

なお, 式（32）における輸送費は各現場ごとに標準的な 容量のトラックで配送, 返送する費用を考えるものとす る.

b) タイプ $\mathrm{V}$ (混合使用不可, 中途切替不可) の定蒫 化

(目的関数)

$$
\begin{aligned}
z_{B_{1}}{ }^{(1)}= & \sum_{k=1}^{K}\left[\left\{\bar{C}_{k}{ }^{I} I_{k}+\sum_{i=1}^{k} \bar{C}_{k i}{ }^{S} P_{i}\right.\right. \\
& \left.+\bar{C}_{k}{ }^{M} \sum_{j=1}^{N} \delta j f \cdot\left(m_{k-1} j-m_{k j}\right)\right\} \\
& -\left\{\bar{C}_{k} U \sum_{j=1}^{N} \delta j_{j} m_{k j}\right.
\end{aligned}
$$

$$
\left.\left.+\bar{C}_{k}{ }^{B} \alpha \sum_{j=1}^{N} \delta_{j} f\left(m_{k-1} j-m_{k j}\right)\right\}\right] \rightarrow \min
$$

$$
\begin{aligned}
z_{B_{z}}{ }^{(1)}= & \sum_{k=1}^{K}\left[\left\{\bar{C}_{k}{ }^{I} I_{k}+\sum_{i=1}^{k} \bar{C}_{k i} S P_{i}\right.\right. \\
& +\bar{C}_{k}{ }^{M} \sum_{j=1}^{N} \delta_{j} f\left(m_{k-1} j-m_{k j}\right) \\
& \left.+\left(\bar{C}_{k}{ }^{R}-\bar{C}_{k} U\right) \sum_{j=1}^{N}\left(1-\delta_{j}\right) m_{k j}\right\} \\
& -\left\{\bar{C}_{k} U \sum_{j=1}^{N} \delta_{j} m_{k j}\right. \\
& \left.\left.+\bar{C}_{k}{ }^{B} \alpha \sum_{j=1}^{N} \delta_{j} f\left(m_{k-1}-m_{k j}\right)\right\}\right] \rightarrow \min
\end{aligned}
$$

$$
\begin{aligned}
z_{C}^{(1)}= & \sum_{k=1}^{K}\left[\bar{C}_{k}^{I} I_{k}+\sum_{i=1}^{k} \bar{C}_{k i}{ }^{S} P_{i}\right. \\
& +\bar{C}_{k}{ }^{M} \sum_{j=1}^{N} \delta_{j} f\left(m_{k-1}-m_{k j}\right) \\
& +\bar{C}_{k}{ }^{R} \sum_{j=1}^{N}\left(1-\delta_{j}\right) m_{k j} \\
& \left.+\bar{C}_{k} B^{\prime} \alpha_{j=1}^{N}\left(1-\delta_{j}\right) f\left(m_{k-1}-m_{k j}\right)\right] \\
& +\sum_{j=1}^{N} C_{j}{ }^{T} \delta_{j}\left(\max _{k} m_{k j}\right) \\
& +\sum_{j=1}^{N} C_{j} T^{\prime}\left(1-\delta_{j}\right)\left(\max _{k} m_{k j}\right) \rightarrow \min
\end{aligned}
$$

ただし，

$$
\begin{aligned}
I_{k}=I_{0} & +(1-\alpha) \sum_{i=1}^{k-2} B_{i}+\sum_{i=1}^{k} P_{i} \\
& -\alpha \sum_{i=1}^{k-2} \sum_{j=1}^{N} \delta_{j} f\left(m_{i j}-m_{i+1}\right)+B_{k-1} \\
& +\sum_{j=1}^{N} \delta_{j} f\left(m_{k-1} j-m_{k j}\right)-\sum_{j=1}^{N} \delta_{j} m_{k j}
\end{aligned}
$$

$$
f(x)=x(x \geqq 0) \text { or } 0 \quad(x<0)
$$

(制約条件)

(1) $\sum_{j=1}^{N} \delta_{j} m_{k j} \leqq I_{0}+(1-\alpha) \sum_{i=1}^{k-2} B_{i}+\sum_{i=1}^{k} P_{i}$

$$
\begin{aligned}
& -\alpha \sum_{i=1}^{k-2} \sum_{j=1}^{N} \delta_{j} f\left(m_{i j}-m_{i+1}\right) \\
& -\sum_{j=1}^{N} \delta_{j} f\left(m_{k-1} j-m_{k j}\right) \quad(k=1,2, \cdots, K)
\end{aligned}
$$

(2) $\underline{S}_{k} \leqq I_{k} \leqq \bar{S}_{k}(k=1,2, \cdots, K)$

(3) $\sum_{k=1}^{K} C_{k}{ }^{P} P_{k} \leqq M$

(4) $H_{1}{ }^{E} \leqq H_{2}{ }^{*}$

ただし。

$$
\begin{aligned}
H_{1}{ }^{E}=I_{0} & +B_{0}+(1-\alpha) \sum_{k=1}^{K} B_{k}+\sum_{k=1}^{K} P_{k} \\
& -\alpha \sum_{k=1}^{K-1} \sum_{j=1}^{N} \delta_{j} f\left(m_{i j}-m_{i+1}\right)
\end{aligned}
$$




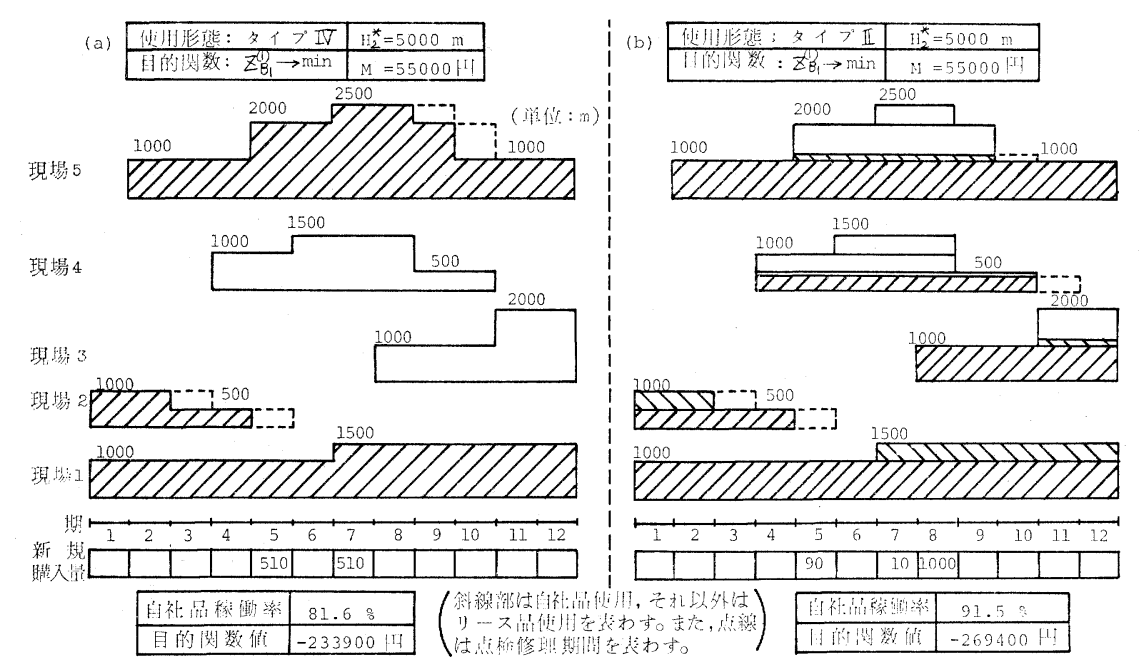

図-7 短期計画モデルの適用結果

(5) $\left.\begin{array}{l}P_{k} \geqq 0 \quad(k=1,2, \cdots, K) \\ \delta_{j}=0 \text { or } 1(j=1,2, \cdots, N)\end{array}\right\}$

\section{（5）短期計画モデルの解法}

タイプII短期計画モデルは $P_{k}, x_{j}$ という $K+N$ 個 の整数型変数をもつ線形整数計画問題となる.この種の 問題は変数の数が多くなると実用的な計算時間内で最適 解を求めることが困難となるため，ここでは整数条件を 外し, 線形計画問題として近似解を求めることにする.

一方, タイプ IV の短期計画モデルは $N$ 個の 0-1 型 変数と $K$ 個の整数型变数をもつ線形整数計画問題とな る.これもタイプ II と同様の理由により， $P_{k}$ の整数条 件を外すことによって得られる 0-1 混合整数計画問題を 相補計画問題として解くことにする.なお，相補計画問 題の解法等については参考文献 7)，8）に譲る.

表一6 適用事例のインプットデータ

\begin{tabular}{|c|c|c|}
\hline $\bar{C}_{k}^{I}$ & 0 & $(円 / m)$ \\
\hline $\bar{C}_{k i} S$ & 4.7 & (円/m) \\
\hline $\bar{C}_{k}^{M}$ & 15.0 & $($ 円 $/ \mathrm{m})$ \\
\hline${\overline{C_{k}}}_{k}$ & 8.0 & $(円 / m)$ \\
\hline $\bar{C}_{k}^{B}$ & 500.0 & $(\mathrm{M} / \mathrm{m})$ \\
\hline $\bar{C}_{k} R$ & 10.0 & $(\mathrm{円} / \mathrm{m})$ \\
\hline $\bar{C}_{k} B^{\prime}$ & 600.0 & $($ 円 $/ \mathrm{m})$ \\
\hline$C_{k}{ }^{P}$ & 500.0 & (円 $/ \mathrm{m})$ \\
\hline$I_{0}$ & 3000 & (m) \\
\hline$\alpha$ & 0.02 & \\
\hline $\bar{S}_{k}$ & 3000 & (m) \\
\hline$\underline{S}_{k}$ & 0 & (m) \\
\hline$M$ & 550000 & (円) \\
\hline$H_{2}{ }^{*}$ & 5000 & (m) \\
\hline
\end{tabular}

\section{（6）短期計画モデルの適用例}

（3）と同様に角パイプを対象品目として本モデルの適 用を試みる.ここでは計画対象期間を半年, 計画単位を 半月とした.また，簡単のため工事現場は 5 か所とし， 各現場の需要量として 図一7 の山積図を考えた. 表一6 には各定数の想定值を示した. 事例計算結果の概要は以 下のとおりである。

(1) $Z_{B_{1}}{ }^{(1)} \rightarrow \min$ を目的関数とする計算結果を示した 図一7によれば，使用形態をタイプI とする場合には現 場 $1,2,5$ で自社品を使用し, 現場 3,4 ではリース品 を使用するとともに, 第 5,7 期に合計 $1020 \mathrm{~m}$ を購入 するのが望ましいといら結果が得られ，このときの目的 関数值は -233900 円であった. また, 自社品稼働率 $r$ を

$$
r=\frac{\left.\sum_{k=1}^{K} \text { (第 } k \text { 期の自社品使用量 }\right)}{\sum_{k=1}^{K} \text { (第 } k \text { 期の自社品保有量) }}
$$

で定義すると，この場合は $81.6 \%$ となる，一方，使用 形態をタイプIIをす場合には現場 $3,4,5$ において自 社品とリース品を混合使用するとともに, 第 $5,7,9$ 期 に合計 $1100 \mathrm{~m}$ を購大するのが望ましいといら結果が得 られ, 目的関数值は -269400 円, 自社品稼働率は 91.5 \%となった. これらの值はいずれもタイプIの場合と比 ベて大幅に改善されている.この結果，資材を経済的・ 効率的に運用するために注同一現場内での自社品とリー ス品の混合使用が有効であることが明らかとなった。

(2) 表-1 は 3 つの異なる目的関数のもとで得られた 最適解についてそれぞれ評価主体別の資材管理費用およ び自社品稼働率を計算したもので, 設定した目的関数に よって解の異なることがみとめられる（それぞれの目的 


\begin{tabular}{|c|c|c|c|c|}
\hline $\begin{array}{l}\text { 資材管理費用 } \\
\text { 目的関数 }\end{array}$ & $z_{B_{1}}^{(1)}$ & $z_{B 2}{ }^{(1)}$ & $z C^{(1)}$ & 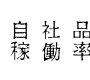 \\
\hline $\begin{array}{l}z_{B_{1}}{ }^{(1)} \rightarrow \min \\
z_{B 2}{ }^{(1)} \rightarrow \min \\
z_{C^{(1)}} \rightarrow \min \end{array}$ & $\begin{array}{l}-233900 \text { 円 } \\
-233900 \\
-223500\end{array}$ & $\begin{array}{l}-204900 \text { 円 } \\
-204900 \\
-189500\end{array}$ & $\begin{array}{l}440000 \text { 円 } \\
440000 \\
412500\end{array}$ & $\begin{array}{l}81.6 \% \\
81.6 \\
79.5\end{array}$ \\
\hline \multicolumn{5}{|l|}{ タイプ II } \\
\hline 目的関数 & $z_{B 1^{(1)}}^{(1)}$ & $z_{B 2}{ }^{(1)}$ & $z_{C^{(1)}}$ & 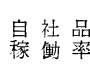 \\
\hline $\begin{array}{l}z_{B_{1}}^{(1)} \rightarrow \min \\
z_{B_{2}}^{(1)} \rightarrow \min \\
z_{C^{(1)}} \rightarrow \min \end{array}$ & $\begin{array}{l}-268500 円 \\
-265500 \\
-254200\end{array}$ & $\begin{array}{l}-244600 円 \\
-245500 \\
-237900\end{array}$ & $\begin{array}{l}375000 \text { 円 } \\
354300 \\
335600\end{array}$ & $\begin{array}{l}91.5 \% \\
89.9 \\
88.6\end{array}$ \\
\hline
\end{tabular}

関数は支出をプラス側にとっているため, 収入の項目が 含まれている $z_{B_{1}}, z_{B_{2}}$ は負の值, 収入の項目がない $z_{C}$ は正の值が得られている).このうち 自社品稼働率につ いてみると $\mathrm{B}_{1}$ で評価する場合が最も高くなっており， 長期計画と同様自社品を最も効率的に運用する立場であ ることがわかる．これに比べて $\mathrm{B}_{2}$ では自社品稼働率が 若干低いが，これはリース料と自社品使用料との差額を 資材センターが負担することからリース量を減らすこと が基本方針となるためである。

\section{4. 資材配送計画モデル ${ }^{9)}$}

この計画モデルは資材センターから各工事現場への自 社品配送業務において複数資材の混載および配送ルート の統合（以下では積合せとよぶ）の積極的な導入によっ て配送費用を低廉化することを目的とし，車種別配車台 数および各トラックの資材積載量, 配送ルートを決定す るものである.この計画問題は混載・積合せという性質 の異なる 2 つの問題を含み, それぞれの代替案数が非常 に多いため, これら 2 つの問題を同時に扱い, かつ最適 性を保証するような計画アルゴリズムを提案することは 困難である。そこで本研究では, まず混載は認めるが個 個の工事現場へ独立にトラックの配車を検討する第 $17^{\circ}$ ロセスと，その結果をもとに複数工事現場への積合せを 検討する第 2 プロセスという 2 段階の計画プロセスから なるモデルを提案する.

\section{（1）第 1 プロセスの資材配送計画モデルとその解法} モデル作成上の前提条件として,

(1) 搬入日が同一の複数現場を対象とし，個々の現場 への複数種類の資材配送量は既知とする.

(2) 各車種の配車可能台数化制限があるものとする.

(3) 各トラックはあらかじめ設定された資材センター と各工事現場間の最短経路を走行するものとする.

(4) 工事現場の立地条件に応じて進入可能なトラック
車種の制限（大型車通行規制等）を考慮する.

を設定すると，第 1 プロセスの資材配送計画モデルは各 工事現場への車種別配車台数と個々のトラックの資材積 載量を変数とする $0-1$ 型整数計画問題として定式化でき る.しかし, その解法関して本研究では,

(i) 第 1 プロセスでの最適解に対して第 2 プロセス で積合せを考慮しても，必ずしも配送計画全体の最適解 となる保証のないこと，

(ii) $0-1$ 変数を含む整数計画問題は変数の数が多く なると実用的な計算時間内に最適解を得にくいこと, を考慮し, 実行可能な近似解を効率よく求めるヒューリ スティックな方法を考えていくことにした，すなわち， まず各現場への車種別・資材別配車台数を実数变数とす る線形計画問題を解き, 以下に示寸手順によって第 $17^{\circ}$ ロセスの配送計画を求めることにする.

手順 1 LP の最適解の整数部分の配車を決定する.

手順 2 手順 1 の配車決定だけでは配送量が不足する 現場に対しては混載を認め, まだ配車決定されていない 大型車を割り当てる.

手順 3 個々の現場に配車決定されたトラック 2 台分 の資材を 1 台のトラックに混載することによって配送費 用を減らすことができるかどうかを検討する。

\section{（2）第 2 プロセスの資材配送計画モデルとその解法}

第 1 プロセスで求まる配送計画に扔いて満載状態とな ったトラックは最適な配送計画もしくはそれに近い計画 代替案の一部を構成するものと考えられるためその配車 を決定し, 満載状態でないトラックのみを第 2 プロセス の対象として積合せによる配送費用の低減化を考えてい くことにする. 本研究ではその解法として Clark と

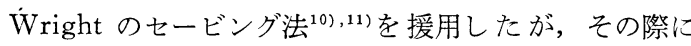
上述の前提条件 (1) (4)以外次の 2 点を考慮している。

(1) 各トラックの走行距離, 走行時間に上限を設定 し，適用事例ではそれぞれ $200 \mathrm{~km} ， 8$ 時間とした。

(2) トラックが工事現場に立寄るごとに荷下しのため の留置時間を要し, 適用事例ではこれを 30 分とした.

\section{（3）適用事例およびその考察}

ここでは混載・積合せが配送費用の低減化に及ぼす効 果を調べるために，大阪府高槻市に位置し近畿一円をそ の管轄区域とする資材センターから 19 工事現場への資 材配送問題を想定し, 対象品目としてトラックへの積載 数量が重量で制限される角パイプ，および容積で制限さ れる鋼製型枠を取り上げた.各工事現場への資材配送量， 資材センターからの距離拉よび進入可能なトラックの最 大車種を示したのが表一8である. トラックの車種に関 しては, $2 \cdot 4 \cdot 6 \cdot 8$ トン車の 4 車種を考え, 配車可能台 
表一8 適用毫例のインプットデータ

\begin{tabular}{|c|c|c|c|c|c|}
\hline & $\begin{array}{l}\text { 現場 } \\
\text { 近在地 }\end{array}$ & 資材センター多 & $\begin{array}{l}\text { 鋼製型染 } \\
\text { 配 送 量 }\end{array}$ & $\begin{array}{l}\text { 角パイブ } \\
\text { 配 送 量 }\end{array}$ & $\begin{array}{l}\text { 隻入可能な最 } \\
\text { 大型トラック }\end{array}$ \\
\hline 1 & 板 宿 & $56 \mathrm{~km}$ & 350 枠 & $445 \mathrm{~m}$ & 6 トン車 \\
\hline 2 & 箂 山 & 71 & 144 & 1527 & 8 \\
\hline 3 & 宝 塚 & 30 & 17 & 9761 & 8 \\
\hline 4 & 西 宮 & 33 & 18 & 120 & 6 \\
\hline 5 & 尼 崎 & 31 & 636 & 1150 & 8 \\
\hline 6 & 豊 中 & 22 & 343 & 960 & 8 \\
\hline 7 & $+\equiv$ & 24 & 367 & 1625 & 4 \\
\hline 8 & 梅 田 & 24 & 44 & 4981 & 4 \\
\hline 9 & 守 口 & 14 & 291 & 2776 & 8 \\
\hline 10 & 東能勢 & 24 & 150 & 574 & 8 \\
\hline 11 & 亀 岡 & 27 & 63 & 175 & 8 \\
\hline 12 & 大 津 & 32 & 240 & 1340 & 8 \\
\hline 13 & 宇 治 & 23 & 570 & 3472 & 8 \\
\hline 14 & 生 駒 & 24 & 78 & 9860 & 8 \\
\hline 15 & 堺 & 37 & 154 & 720 & 8 \\
\hline 16 & 羽曳野 & 41 & 20 & 215 & 8 \\
\hline 17 & 天 野 & 47 & 471 & 3270 & 8 \\
\hline 18 & 岸和田 & 53 & 170 & 7153 & 8 \\
\hline 19 & 和歌山 & 89 & 54 & 1520 & 8 \\
\hline
\end{tabular}

数をそれぞれ 20 台, 20 台, 25 台, 25 台と仮定した.

さて，混載・積合せの採否によって，ケースA；混 載・積合せとも認めない場合, ケース $\mathrm{B}$; 積合せのみ認 める場合, ケース $\mathrm{C}$; 混載のみ認める場合, ケース $\mathrm{D}$; 混載・積合せとも認める場合, の 4 ケースを考え, それ ぞれの適用結果をまとめたのが 表一9である.ケース $\mathrm{A}$ と C，ケース B とDをそれぞれ比較することにより，混 載を認めた配送計画では積載率および大型車の配車比率 が向上し, 総走行距離およびトラック配車台数が減少す ることが明らかとなった。これらはいずれも配送費用の 低減化に結びっくものであり; 事実ケース C, D 配送費 用はケース A， B よりもかなり少なくなっている. 一 方, 積合せに関してもケース $\mathrm{A}$ と $\mathrm{B}$, ケース $\mathrm{C}$ と $\mathrm{D}$ を比 較することにより同様の特徵を認めることができる. 以 上のことから，混載・積合せは配送費用の低減化といら 目的に対して有効に機能することが明らかとなった。

\section{5. 結言}

本研究は建設用仮設資材の管理・配送業務に対し, 合 理的な資材管理・配送計画を作成するためのシステム ズ・アプローチを試みたものである.すなわち, 資材管 理計画に関しては 0-1 型混合整数計画問題等の最適化手 法を組み込んだ計画モデル, 資材配送計画に関しては線 形計画問題およびセービング法等を組み込んだヒューリ スティックな計画モデルを提案したもので,この結果, 客 観的かつシスティマティックな計画代替案の立案ならび に評価検討が可能となった．また，事例計算を通してこ れらの計画モデルが十分有効に機能することも明らかと なった. しかしながら, 今後本研究をさらに発展させる
表一9資材配送計画モデルの適用結果

\begin{tabular}{|c|c|c|c|c|c|}
\hline & ケースA & ケースB & ケースC & ケースD \\
\hline \multirow{4}{*}{$\begin{array}{l}\text { 户 } \\
\bar{y} \\
\text { y } \\
\text { 台 } \\
\text { 数 }\end{array}$} & $\begin{array}{l}8 \text { トン車 } \\
6 \text { トン車 }\end{array}$ & $\begin{array}{l}18 \text { 台 } \\
21\end{array}$ & $\begin{array}{l}21 \text { 台 } \\
19\end{array}$ & $\begin{array}{l}25 \text { 台 } \\
15\end{array}$ & $\begin{array}{l}25 \text { 台 } \\
15\end{array}$ \\
\hline & 4 トン車 & 18 & 14 & 9 & 11 \\
\hline & 2 トン車 & 16 & 4 & 14 & 3 \\
\hline & 合 計 & 73 & 58 & 63 & 54 \\
\hline \multicolumn{2}{|c|}{ 配 送費 用 } & 771680 円 & 684330 円 & 694420 円 & 639590 円 \\
\hline & 載 率 & $86.2 \%$ & $95.6 \%$ & $91.4 \%$ & $98.5 \%$ \\
\hline \multicolumn{2}{|c|}{ 総走行距離 } & $2465 \mathrm{~km}$ & $2129 \mathrm{~km}$ & $2152 \mathrm{~km}$ & $1936 \mathrm{~km}$ \\
\hline \multicolumn{2}{|c|}{ 平均走行距離 } & $33.8 \mathrm{~km}$ & $36.7 \mathrm{~km}$ & $34.2 \mathrm{~km}$ & $35.9 \mathrm{~km}$ \\
\hline
\end{tabular}

ためには次のような課題を考えていく必要がある.

(1) 本研究で提案した資材管理計画は単一品目を対象 としたものであるが，今後は複数種類の資材を同時に扱 い得る計画モデルに拡張すること.

(2) 資材管理計画で考虑した計画要素とそれ以外の管 理要素 (品質, 廃棄基準, 点検修理能力等) との関連, および資材管理計画と資材配送計画との整合性について さらに詳細に検討すること．

最後に本研究を遂行するにあたり有益なご助言をいた だいた京都大学工学部 春名 攻助教授, ならびに心よく 資料を提供して下さった関係各位に謝意を表します。ま た, 本研究は水野温夫氏 (現在, 中央復建コンサルタン 卜勤務) ならびに瀬戸 馨氏 (現在, 建設省勤務) の労 に負うところが大きく，心から感謝する次第である。

\section{参 考 文 献}

1）山本幸司：土木工事に打ける施工計画のシステム化に関 する研究, 京都大学学位論文, pp. 131 174, 1978.

2）飯吉精一：建設産業の機材管理, 技報堂, 1968 .

3）倉林良雄 - 本間郁雄 - 南川利雄 : 資材管理, 森北出版, 1977.

4）川崎健次・春名 攻・田坂隆一郎：工作所における仮設機 材管理, 第 6 回業務研究発表会論文集, pp. $3 \sim 24$, 建設 コンサルタンツ協会, 1973.

5）吉田信夫：土木技術者への計画と管理のための予測手法, 山海堂, 1974.

6）鈴木久子・大石展緒・荻津好文：実例による需要予測の 技法, 日刊工業新聞社, 1972 .

7）茨木俊秀: 相補的プログラミング, 経営科学, 第 16 巻, 第 1 号, pp. 33〜 51, 1972.

8) Gottle, R.W. and G.B. Dantig : Complementary Pivot Theory of Mathematical Programming, J. of Linear Algebra and Its Applications, Vol. 1, pp. 103 125, 1968.

9）吉川和広・山本幸司・瀬戸 馨：混載・積合せを考慮した 仮設材配送計画の合理化, 第 33 回年次学術講演会講演概 要集第 4 部, 土木学会, 1978 .

10) Clark, G. and J.W. Wright : Scheduling of Vehicles from a Central Depot to a Number of Delivery Points, Operations Research Quarterly, Vol. 18, No. 3, 1967.

11）阿保栄司：物流ソフトウェアの実際, 日刊工業新聞社, pp. 113 144, 1977.

(1980.10.3 - 受付) 